\title{
ALTERNATIVE MODEL FOR PUTTING INDONESIAN YOUNG DIGITAL TALENT IN BUSINESS
}

\author{
Eka Sudarmaji, Mira Munirah \\ Faculty of Economics \& Business, University of Pancasila
}

\begin{abstract}
This paper explores the experiential teaching of 'work \& innovation-based' learning entrepreneurship through a Lean Startup Methodology (LSM). The LSM is a practical framework for entrepreneurship students to test whether their new innovation idea meets customers' expectations. The iterative approach, according to LSM, to develop new innovation-based products is used and LSM was compiled into a number of principles. The students have been forced to implement LSM in early-phase ventures. This study investigated several factors that influenced prospective young entrepreneurs in Entrepreneurship Education within students, based on a sample of 225 university students. The research model used the 'Non-Equivalent Groups Design' (NEGD) framework for both 'observed group' and 'control group'. The results of this study showed that "Perceived Desirability" and "Perceived Feasibility" have impacted on Entrepreneurial Intentions in an integrated environment of higher education. The descriptive statistic and MANOVA Analysis were used to analyze the Entrepreneurial Intentions of young digital talents.
\end{abstract}

Keywords: Entrepreneurship Education and Intentions; Lean Startup Methodology (LSM); Perceived Desirability and Feasibility.

\section{INTRODUCTION}

The inevitable shift from the era of simple digitalization, or the third industrial revolution, to innovation based on a combination of technology, or the fourth industrial revolution, forced many organizations to reassess their way of doing business. The current development does not change the fundamentals of doing business, and the philosophy of business remains the same. Therefore, organizational leaders and senior executives need to understand the changing

\footnotetext{
*Corresponding Author.

e-mail: esudarmaji@univpancasila.ac.id
} 
corporate environment, take the initiative to fight outdated business assumptions, and try strategies to be run by their entire operations team, and continue to innovate. In science and technology innovation, SMEs in China and India have made great progress in technological innovation to become the driving force behind the spread and application of new technologies and innovations. At the end of 2003, China established 40 service centers for SME technology innovation and more than 500 product promotion centers (R. K. Singh, Garg, \& Deshmukh, 2010) and this institution provided strong support for technological innovations in Chinese SMEs (Chen, 2006). At the same time, India also develops and uses e-business technology in the export market (Lal, 2004).

On the supply side, many entrepreneurs see that the introduction of new technology creates new ways to fully serve existing needs, and significantly disrupt the industry's existing value chains. This was the result of new, agile and innovative entrepreneurs getting access to global digital platforms, both for research, development, marketing, sales and distribution. Major shifts also occur on the demand side as is a result of growing transparency, consumer involvement, and new consumer behavior patterns that change rapidly because they are built on network access and cellular data. Therefore, companies must adjust the way they design, market, and deliver products and services to customers.

Cellular technology platforms can collect individuals, assets, and data, thus creating new ways of how customers consume goods and services. In addition, this platform also reduces barriers for businesspeople and individuals to create wealth and also change the personal and professional environment. This new business platform quickly creates many new services, from laundry services to shopping, from work to parking, from massage services to travel services. An innovative business model using a digital platform can create new markets or allow new entrepreneurs to create and take advantage of new opportunities in existing markets. Indonesia's young generation is now very familiar to the internet and digital technology, hence the total number of internet users of 132.7 million by 2016. 24.5\% of Indonesians are at a productive age, and from 20202035 Indonesia will enjoy bonuses from this demography. The number of this productive age is projected to be on the highest in the nation's history, which is $64 \%$ of the 297 million population of Indonesia. Regarding how young people, mostly in the campus environment, become new entrepreneurs is the first task 
Eka Sudarmaji, Mira Munirah / Alternative Model for Putting Indonesian Young Digital Talent in Business

of lecturers to motivate and develop entrepreneurial spirit in the campus environment (Goodwin \& Martam, 2014).

Formal education is not always the situation in which the dynamics of entrepreneurship emerge. The education system in Indonesia sees that entrepreneurship education is the most appropriate and capable vessel to fulfill the campus accreditation function. However, when entrepreneurship education spreads in the community, it can create a chain effect. In developed countries (OECD), local development efforts unite and coordinate authorities, civic organizations, business communities, and schools to increase entrepreneurship, including young entrepreneurs as a source of economic dynamic and new jobs (Hagen, 2008; Organization For Economic Co. Operation and Development (OECD), 2001). Education to prepare potential entrepreneurs is an important part of the efforts to increase entrepreneurship.

The Young Entrepreneurs Scheme (YES) in Ireland was created in 1991, which targets children aged 12-18 years. The ultimate goal is to develop a strong corporate culture to encourage young Irish people to set up their own business one day, help them to deal with changing work situations, and encourage initiative, creativity, and entrepreneurial skills. In 1997, the Greek Ministry of Labor and Social Affairs established a grant program to encourage 2500 new small businesses and self-employed workers, targeting unemployed people who have a technical diploma aged 18-25 years. While in Portugal, Sistema de Apoio aos Jovens Empresarios (SAJE) provides grants for new businesses, which cover $50 \%$ of capital needs, $10 \%$ for projects in disadvantaged areas, and another $10 \%$ is aimed at unemployment and young job seekers. The Wissenschafter Grunden Firmen program in Austria provides a fairly standard financial package and assistance tailored to the narrow target run by the Ministry of Science, which is to assist scientists with viable business projects with most clients aged between 25 and 33 years. The Escuelas Taller Program from Spain began in 1994, funded by the Spanish National Labor Institute and the European Social Fund, with the aim of facilitating youth unemployment (aged 18-25 years) with limited professional skills (Goodwin \& Martam, 2014).

Related to conditions in Indonesia, the Indonesian National Qualification Framework ("KKNI") is a guideline for tertiary institutions to compile a curriculum containing the objectives of the study program, as well as relevant 
subjects to achieve the goals set out in the IQF (Maksum, 2015). The aim of $\mathrm{KKNI}$ is to match the curriculum with the needs of all stakeholders as employers of formal education graduates. Some empirical evidence show that entrepreneurship courses, education, and workshops, including the KKNI program, play an important role in improving entrepreneurship skills on campus. Entrepreneurship training may not only stimulate the ability to identify opportunities and improve skills, but also influence the 'desirability' and 'feasibility' of students as prospective new entrepreneurs based on digital technology (technopreneur) (DeTienne \& Chandler, 2004; Fiet , 2007; Wright \& Fu, 2015). Several empirical findings note that training and education inspire and have a moderate level of impact on entrepreneurial intentions, especially in the field of technopreneur (DeTienne \& Chandler, 2004; Fiet, 2007).

This research explores the 'desirability' and 'feasibility', as well as students' decisions to adopt digital technology that influences choices in their business and university life. This research also explores the potential of new entrepreneurs in the field of creative industries that use digital technology media. In e-commerce classes, digital technology training is expected to provide students with the expertise and technological skills that can be integrated into desirability and feasibility, and encourage the adoption of digital technology in their business choices (Moghavvemi, Salleh, \& Abessi, 2013; Straub, 2009). Therefore, the authors hope that this research will provide clear insights, such as in learning or training that is work $\&$ innovation-based to encourage the desires and beliefs of prospective entrepreneurs in the Faculty of Business Economics, Pancasila University.

Recent Empirical literatures that discussed the behavior of new entrepreneurs and how they start their businesses also noted that entrepreneurial education seems to be an important antecedent, because evidence in previous researches showed that there is a clear relationship between entrepreneurship education and entrepreneurial activities (Galloway \& Brown, 2002; Henderson \& Robertson, 2000), and it takes a variety of skills/characters to become entrepreneurs (Lazear, 2005).

Entrepreneurship is comprehensive and has several important characteristic components, and thus, it continues to be studied alongside managerial skills on the other hand. Guiso (2016) also found a number of positive relationships that signifies entrepreneurs who grew up in locations where entrepreneurship developed had significantly better managerial practices. 
Empirical literature argues that entrepreneurial intentions depend on Perceived desirability and belief (Perceived Feasibility). A negative interaction effect is found between Perceived desirability and belief (Perceived Feasibility) based on the 'regulatory focus theory'. His findings indicated a new typology of techno-entrepreneurs as natural entrepreneurs, accidental entrepreneurs, and inevitable entrepreneurs. Understanding entrepreneurial desires is important to give our understanding of the study of entrepreneurial behavior (Venkataraman \& Sarasvathy, 2000). Krueger (2004) has determined that the initial factor of entrepreneurial intentions is characterized by Perceived Desirability and Confidence (Perceived Feasibility) arising from entrepreneurial opportunities (Krueger, 2003). Steel and Konig (2006) argued that perceived belief (perceived feasibility) is in line with expectations and perceived desirability in harmony with emotions, so that they may interact in forming entrepreneurial intentions.

In the case of Indonesia, desirability and confidence (feasibility) in the university environment have important aspects in shaping students to become technopreneurs (Sudarmaji \& Ambarwati, 2018). Investigating using the UTAUT theory, it was found that students today looked at entrepreneurs as their goal after their studies. This is in line with the programs of many universities that have entrepreneurship units and business incubators. This study takes the study population of students of the Faculty of Economics and Business, Pancasila University. This is due to the fact that Pancasila University has not implemented the "work \& innovation-base learning" program intensively and had not included it in the curriculum. The population consists of 5 classes of e-commerce courses, totaling in 225 students. The author gets one class as a lecturer in which the class consisted of about 40 students, which are treated as the 'observed class' variable, while the other 4 classes are taken care of by different subjects into a control variable (control class). In the observed class variable, students are grouped into several groups to facilitate and provide a real picture about teamwork in business.

\section{1 a (PD)}

The "Entrepreneur Potential Model (EPM)", (Krueger Jr. \& Brazeal, 1994), confirms that this EPM records two variables in "Theory Planned 
Behvior" or "Theory of reasoned action", that is, attitudes towards actions and social norms which is the basis of EPM. Entrepreneurial motivation and intention to work alone are significantly determined by Perceived desirability. Thrikawala (2011) revealed that gender, family business experience, type of study program and year of study program significantly influenced entrepreneurial intentions among academics while their family's financial capabilities were not related to their goals. In addition, (Barrett, Davidson, Prabhu, \& Vargo, 2015; Davidsson, 2011) suggested that the main determinant of entrepreneurial intention is one's belief that starting and running one's own company is a suitable alternative for him. In addition, Kumara (2012) stated that there is a significant positive correlation between entrepreneurial trust and entrepreneurial intention, and between attitudes towards entrepreneurs and entrepreneurial intentions. Crant (1996) showed a strong relationship between variables in the Entrepreneurial Potential Model. Meanwhile, Veciana, Aponte, and Urbano (2005) revealed that students had a positive vision of wanting to start a new company, but they did not consider it feasible.

\subsection{Perceived Feasibility (PF)}

As explained earlier, 'Theory of Planned Behavior' is an extension of 'Theory of Reasoned Action', (Ajzen \& Fishbein, 2000). Meanwhile, the EPM model (Krueger Jr. \& Brazeal, 1994), where 'Perceived Feasibility' is considered as the same as 'Perceived Behavior' in 'Theory of reasoned action' (I. Singh, Raut, \& Prasad, 2012). This expanded EPM model has included the variable 'Perceived Feasibility' as a non-motivational factor for entrepreneurial intentions. 'Perceived Behavior' has also been referred to as 'Perceived Feasibility', especially in studies measuring entrepreneurial intentions (Krueger Jr., Reilly, \& Carsrud, 2000; Peterman \& Kennedy, 2003). The perception of self-efficacy is also used as 'Perceived Behavior', which is felt in 'Theory of Planned Behavior' by Conner and Armitage (1998). Furthermore, Wang, Lu, and Millington (2011) showed that, 'Perceived Feasibility' in the Entrepreneurial Event Model (Shapero \& Sokol - 1982) has the same meaning or is synonymous in the self-efficacy variable of Ajzen's 'Perceived Behavior' model - 1991 (Krueger Jr. \& Brazeal, 1994). 


\subsection{Entrepreneurship Education (EE)}

The ability to see student business opportunities can be improved through the provision of entrepreneurship courses and training (Japan-ASEAN Integration Fund (JAIF), 2017; Mansor \& Othman, 2011; Muñoz, Mosey, \& Binks, 2011; Sudarmaji \& Ambarwati, 2018). If the ability to identify opportunities can be improved, there are still special factors attached to each individual subject to change during the course and training, where there are certain students who have more ability to identify business opportunities (Muñoz et al., 2011; Nasip $\&$ Sudarmaji, 2017). Some authors find that the ability of entrepreneurs to identify business opportunities can be related to individual characters (Baron, 2004; Gaglio \& Katz, 2001; Krueger Jr. et al., 2000; Nasip \& Sudarmaji, 2017; Sudarmaji \& Ambarwati, 2018). The ability to identify business opportunities must be developed over time, and this can explain why entrepreneurs are able to understand a different reality from other individuals. Students can link information they get from the outside environment, and identify these business opportunities.

Muñoz, Mosey \& Binks (2011) compared changes in visual representation and oral interviews to see changes in students' abilities in identifying business opportunities and understanding of entrepreneurship. They interviewed the best out of 1,800 students from three different Nottingham University campuses: 850 students in the UK, 700 students in China, and 250 students in Malaysia. Muñoz et al. proved that through training, 12 students out of the 15 best students were found to experience changes in character, and training can improve their entrepreneurial abilities. Karimi, Biemans, Lans, Aazami, \& Mulder, (2014), developed special models and also provided training that can enhance the creativity and ability of individuals to develop ways of thinking differently, so that those who have been trained can have the ability to generate business ideas and problem-solving skills. Through training, Nasip and Eka Sudarmaji (2017) measured the ability to identify business opportunities by using the "presentation visualization" indicator. BMC content data is used as a tool to present 'visualization' in training for MSME entrepreneurs. With the change in visualization presentation in the BMC entry data, it is assumed that participants have reacted to changes in knowledge, especially regarding their business concepts. 
Additional training or lessons on how to actually target customers in the business world provide new insights for students in e-commerce and entrepreneurship courses. This is because there are certain segments that training in ecommerce or entrepreneurship subjects that does not teach cognitive things such as creativity, passion (passion), perseverance (perseverance), vision, and the courage to take risks. On the other hand, some things can be taught to students in carrying out their functions as entrepreneurs, such as: business negotiations, business planning, targeting "customer pitching", market research, business plans, and such.

Training in targeting customers is a lesson in how advertisements can deliver the desired results. Successful targeting must show that marketers can use marketing budgets effectively to create greater value for the brand, product or service offered. Targeting ads to relevant customers can empower students to reach large-scale audiences through segmentation or demographic targeting: gender, age, education, and others.

To become new technopreneurs, students must have experience coupled with knowledge about shopping on digital technology platforms, and believe that they can design their own products, market them, and get the benefits. This study was designed through cognitive approaches and learning and was conducted by studying individual orientations of prospective new entrepreneurs, which might differ for each individual, gender, class, age, habits, culture, and others. Then, the next step is to provide learning based on work \& innovationbased learning to improve entrepreneurial character, as it is hoped that students will be able to visualize the ability to pursue future business opportunities.

\subsection{Lean Startup Model (LSM)}

Many entrepreneurship learning programs use traditional teaching approaches, which is theoretical teaching of entrepreneurship. In LSM, teaching is not only based on theory and framework, but students will gain direct experience on how to start a new business or company. More than a quarter of the respondents involved or as many as 40 students as observed variables, used LSMs to be able to work in real practice, to build and produce prototypes that are directly related to suppliers and talk to prospective customers to get accurate 
Eka Sudarmaji, Mira Munirah / Alternative Model for Putting Indonesian Young Digital Talent in Business

information. The goal is that students can directly connect with partners or customers to test and validate their hypotheses, and verify all business models they will run.

The teaching technique emphasizes work experience in learning entrepreneurship, based on innovation or work \& innovation-based learning, that the idea behind this LSM method is the end result of the training process, which is different from traditional training. LSM is a recursive model that tests and validates the initial assumptions of hypotheses made by students. The focus of this initial hypothesis is that students work to test and validate business model innovations. The company's business model is a system of interrelated and interdependent activities that control the way companies do businesses with consumers, partners, and vendors. The business model is a group of special activity systems that are carried out to meet market needs, as well as the specifications that a company or its partners do in their business, and how all these activities are connected to each other. Meanwhile, LSMs are teaching where students start a business startup process as a discovery process that focuses on customer validation and customer development, and how they should continue to repeat it between where customer needs and product requirements are produced, to have complete harmony between the two.

The media used to test the initial hypothesis consists of the 9-block Business Model Canvas. The Business Model Canvas ("BMC") according to Osterwalder, Pigneur, Smith, \& Movement (2010) is an analytical tool on how companies can create corporate value. Through BMC, entrepreneurs can see how they can run their business; who will be involved in the production, marketing, and other departments; and how companies maintain their relationships with customers, so they can also maintain the sustainability of their company. The advantage of BMC is for strategic planning and development; a tool for expressing ideas; tools for knowing customers; as a dashboard / indicator; and tools to understand competitors (such as the level of competition). Besides all that, BMC can also be used as a tool for analyzing business portfolio models; innovation planning; and to harmonize the organizational mindset (Osterwalder \& Pigneur, 2010). 


\section{RESEARCH METHODOLOGY}

This research will begin by investigating students in e-commerce and entrepreneurship classes, to see whether they are interested in becoming new entrepreneurs in the technology-based creative industry or not. In these classes, students are trained to look for experience and added knowledge about shopping on digital technology platforms. For students, starting a business from scratch means learning from mistakes firsthand. They have to deal with customers, employees, and other organizations, and this can be considered as an opportunity to increase their knowledge.

This research explores the decision whether these students are able to adopt specific technologies that affect their business choices and entrepreneurial life at the university. In addition, this study also discusses the potential of new entrepreneurs who come from the campus environment in the field of creative industries and the adoption of certain technologies. E-commerce technology skills are integrated into the current curriculum and are expected to encourage the adoption of certain technologies (Barron, Kemker, Harmes, \& Kalaydjian, 2003; Moghavvemi et al., 2013; Straub, 2009). Therefore, this research is expected to provide answers and clear insights on why Indonesian millennials, especially in the Faculty of Economics and Business, University of Pancasila, remain hesitant to act in adopting and investing in start-up businesses.

The implementation of this research activity is carried out in the form of lectures $(50 \%)$, and the rest is done in group work and creating product sample designs or applications (50\%). This is done by providing examples of business cases that have previously occurred. After participating in courses, students will be given time for consultation / to discuss about business in Small Business Groups guided by the author.

This training effort is expected to motivate and reduce the obstacles experienced by prospective millennipreneurs in starting new technology-based entrepreneurial businesses, especially in being able to see opportunities and position products in existing markets, as well as other matters related to how to start new entrepreneurial businesses. The training is an attempt to enrich and increase the confidence of future millennipreneur candidates. With this activity, prospective millennipreneurs are expected to: 
Eka Sudarmaji, Mira Munirah / Alternative Model for Putting Indonesian Young Digital Talent in Business

1. Have knowledge of contracts, products, prices, services, and financial statement projections.

2. Able to grow his business and become a sustainable business.

3. Able to produce distinctive products or services, differentiate from others, of good quality, and attractive to the market.

4. Able to carry out effective and efficient marketing techniques, so that their products or services can be sold in the market.

The main strategy of this study in e-commerce courses is to provide additional training or lessons in the observation or intervention class (one class) which is used as an 'observed' variable to the other 'control' classes (four classes). In the observed class, special training or e-commerce subjects are added specifically for 30 minutes.

It can be said that this study uses an experimental method with NonEquivalent Groups Design ("NEGD"), which is the form of research most often used in social researches (Enkel, Bell, \& Hogenkamp, 2011; Shadish, Cook, \& Campbell, 2002). NEGD appears when program participants are treated differently. This study, divided into two groups, namely the observed class (selfselected), and the control group (randomly selected), so that the two groups become an unequal part in the way they are recruited and treated. The research framework can be described as follows:

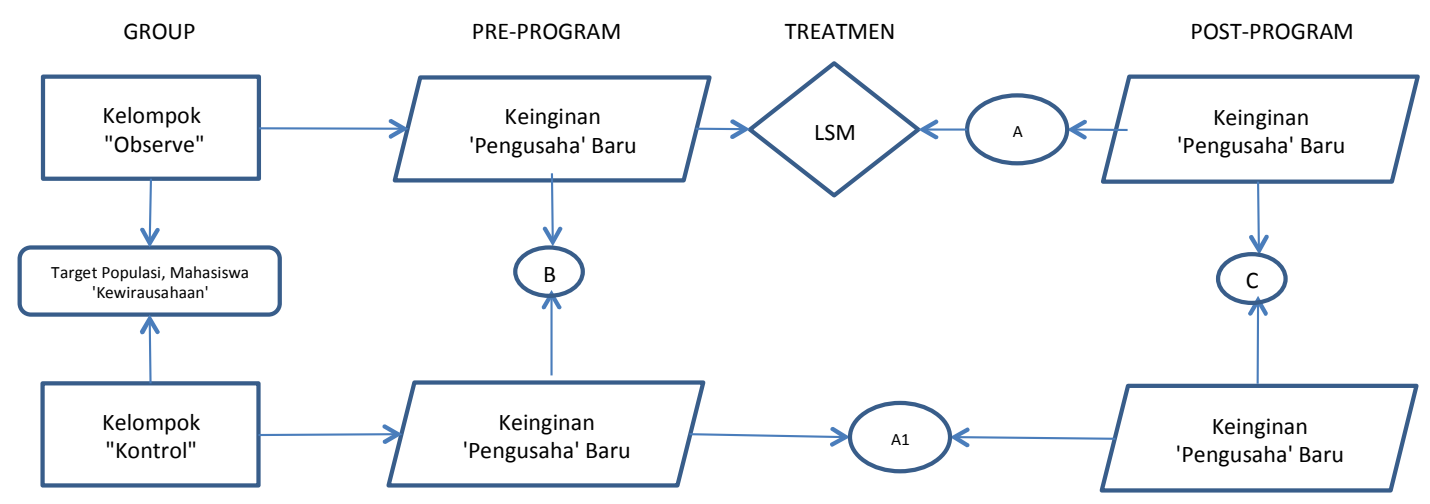

Picture 1 Research Framework

Special additional courses provided in research classes are training students to target customers in marketing their products in real businesses. The lesson on how to target customers or pitching the customer is to use an 
approach: 1) best practices \& using entrepreneurship tools (FB Ads or Instagram Ads), 2) emphasizing practice, 3) localizing MY teaching approach or deviation from GPBB, and 4) evaluating the performance.

This research was arranged through several steps to get a comparison of different training results: 1) the initial questionnaire using Google Form was given at the beginning of the class in all classes including in the observed class and control classes, 2) prospective millennipreneurs are required to make an initial presentation reviewing the business planning, resources, and idea formation. The lessons given in this session are considered to repeat the previous course, namely the entrepreneurship course, whereas the only difference lies in the products that must be sold. Culinary product ideas in e-commerce classes are prohibited from being displayed, because this training intends to encourage the use of digital characteristics and digital terminology on product ideas, 3) prospective millennipreneurs make a second presentation and prospective millennipreneurs are expected to have finished making sample products or initial products which are ready to be marketed and ready to target customers. This training clearly imitates the business and the initial product, in which the creation of a minimum viable product or MVP (minimum viable product) had already taken place, 3 ) prospective millennipreneurs start advertising by actually targeting customers through paid advertisements on Facebook, and 4) the final questionnaire is distributed to see the real effects after prospective millennipreneurs conduct a series of additional subject training activities. The questionnaire is distributed via Google Form to the observed and control class variables.

\section{RESULTS AND DISCUSSION}

The study population consisted of 5 e-commerce classes, totaling in around 225 prospective millennipreneurs. The author gets one class (BMP Class) which contains as many as 40 students, which are treated as an observed class variable in the class action research, while the other 4 classes become the control variables (control classes). In the observed class variable, students are placed into several groups in order to facilitate and provide a real picture about teamwork in business. There are 113 respondents who participated from the ecommerce class. As can be seen in Graph 1., out of 113 student respondents, 78 students 
had an interest in becoming technopreneurs, 15 students did not have a clear picture, and only 10 students stated that they were not interested. In addition, there were 79 students who currently have business ideas, 25 students who do not know of the ideas, and 9 students who have no ideas at all.

Introduction to Business and Entrepreneurship class, as well as Advanced Entrepreneurship, are compulsory subjects for students before they take the ecommerce class. The collection of ideas, lessons, and motivations provided by previous subject lecturers provided a clear picture on how one day they will run a business and carry out their role in it.

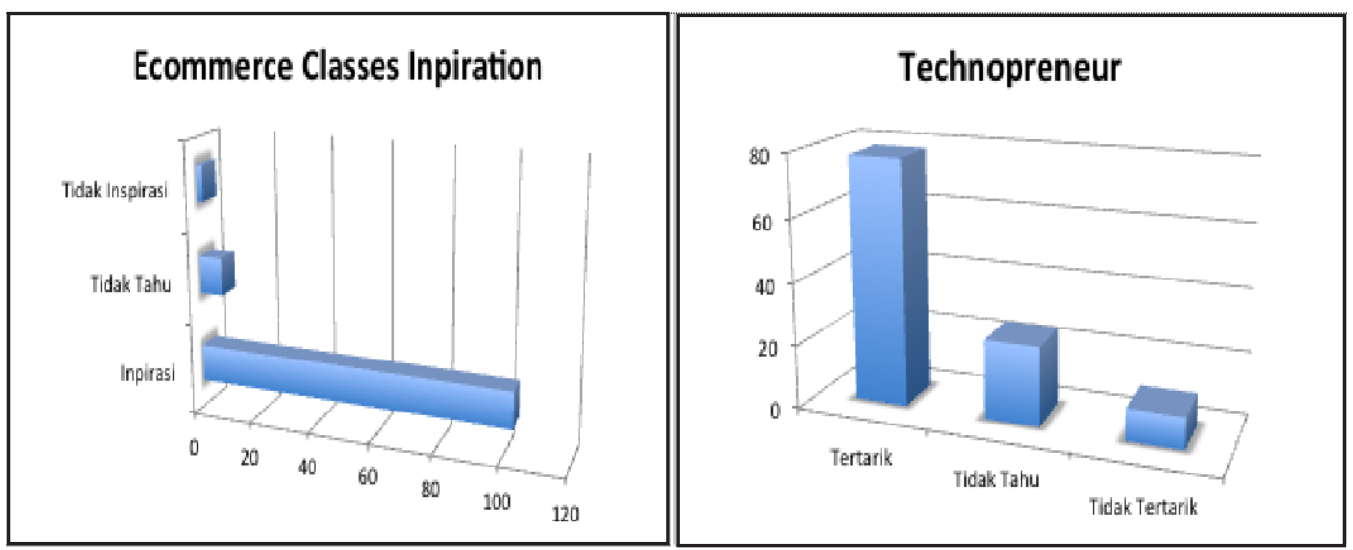

Chart 1 Students Expecting to be Inspired in the E-Commerce class

\subsection{Product Presentation and Customer Targeting}

After students make a preliminary presentation on business planning, resources, and idea formation, then the students are asked to make a presentation about creating minimum viable products. Students at this stage have finished making sample products or initial products that are ready to be marketed and ready to target customers. In this training, students imitate real businesses. After creating the initial product, the next step is how students target customers.

Work learning \& innovation-based learning requires students to promote advertisements and pay for it from their own pockets. This is expected to provide motivation and sincerity for them. Advertising is done through paid Facebook ads. Through paid advertisements, prospective millennipreneurs can 
monitor the movement of advertisements through the dashboard/control board and respond to the interests or questions of prospective customers. The dashboard on Facebook gives an overview of update results on targeted advertisements to customers on Facebook. All responses that come from Facebook, both likes and comments and even requests for goods, will be listed there. This makes it easy for students to see tangible outcome on the initial product being marketed.

\subsection{Entrepreneurship Intention, Perceived Feasibility and Perceived Desirability}

There were 56 respondents who participated in the final questionnaire to see the real effect after students conducted a series of additional subject training activities. Questionnaires are distributed to the observed and control classes via GoogleForm. Of the 56 student respondents, 23 students came from the observed class, and 36 students came from the control class. It can be seen in Table 1 that fromn23 students of the observed class and 36 students of the control class, there was a striking difference which was $16.30 \%$ from the observed class stating that the e-commerce class was interesting and inspired them to become technopreneur.

Table 1 Comparison of Observed Class $(n=23)$ and Control Class $(n=36)$

\begin{tabular}{|l|c|c|c|c|c}
\hline Description & Observed & $\%$ & Control & $\%$ & Var \\
\hline \hline Technopreneur & & & & & \\
\hline Interested & 21 & $91.3 \%$ & 27 & $75.0 \%$ & $\mathbf{1 6 . 3 \%}$ \\
\hline Don't Know & 2 & $8.7 \%$ & 9 & $25.0 \%$ & $-16.3 \%$ \\
\hline Having a Business Idea already & & & & & \\
\hline Don't have & 11 & $47.8 \%$ & 28 & $77.8 \%$ & $-\mathbf{3 0 . 0 \%}$ \\
\hline They do & 12 & $52.2 \%$ & 8 & $22.2 \%$ & $30.0 \%$ \\
\hline Times to Technoprenuer Dream & & & & & \\
\hline 5-10 Years upon Graduation and Work & 0 & $0.0 \%$ & 2 & $5.6 \%$ & $-5.6 \%$ \\
\hline 2-3 Years upon Graduation and Work & 1 & $4.3 \%$ & 18 & $50.0 \%$ & $-45.7 \%$ \\
\hline Undecided & 1 & $4.3 \%$ & 5 & $13.9 \%$ & $-9.5 \%$ \\
\hline Upon Graduation & 21 & $91.3 \%$ & 11 & $30.6 \%$ & $60.7 \%$ \\
\hline Segment Ecommerce & & & & & \\
\hline Both of Business \& Technology & 6 & $26.1 \%$ & 10 & $27.8 \%$ & $-1.7 \%$ \\
\hline Business Section & 16 & $69.6 \%$ & 23 & $63.9 \%$ & $5.7 \%$ \\
\hline Technical Section & 1 & $4.3 \%$ & 3 & $8.3 \%$ & $-4.0 \%$ \\
\hline Inspire by ecommerce & \multicolumn{1}{|l|}{} & & & & \\
\hline Maybe & 6 & $26.1 \%$ & 11 & $30.6 \%$ & $-4.5 \%$ \\
\hline Yes & 17 & $73.9 \%$ & 25 & $69.4 \%$ & $4.5 \%$ \\
\hline
\end{tabular}


Meanwhile, when asked whether they currently have any business idea that they will one day implement, as can be seen in Table 1, there are $52.50 \%$ in the observed class who already have an idea and $47.80 \%$ do not have any idea. This far exceeds the percentage when compared with the control class, which is $22.20 \%$ who already have a business idea, and $77.80 \%$ who do not have a business idea.

Inspiration to carry out or execute business ideas is usually determined by many things and are cognitive in nature, such as creativity, passion, perseverance, vision, and the courage to take risks. Of the 23 students who came from the observed class, there was a very sharp difference where $91.30 \%$ stated that they would execute a business idea after graduating from college, and the rest had not decided yet, and would implement it within 2-3 years after graduating.

This is inversely proportional to 36 students taken from the control class, where only $30.60 \%$ will carry out their business ideas after graduating from college, 50\% will implement them in 2-3 years after graduating from college, and the rest, $13.90 \%$ and $5.60 \%$, decided to implement their ideas $5-10$ years after graduation, and that hasn't been decided at all, respectively. Still in Table 1 above, although there are still differences in 23 students who are in the observed variable and 36 students in the control class, but the difference is very thin. There were $69.60 \%$ and $63.90 \%$ of students from both classes who chose business-weighted weight or segments in e-commerce classes compared to technical segment lectures, while the difference between the observed and control classes was only $5.70 \%$. So, it can be said that lectures with business segments and examples of contemporary subjects can inspire and attract students to attend this e-commerce course.

In addition, when asked whether they are still inspired and will practice part or all of e-commerce lessons, such as business negotiations, business planning, attracting customers, market research, and business plans, almost all of them answer "yes", amounting to $73.90 \%$ of the observed class and $69.40 \%$ of the control class.

\section{MANOVA Results}

Based on multivariate test analysis, it can be stated that there is a very significant difference between the observed class and the control class. By using 
Review of Management and Entrepreneurship

Volume 03, Number 01, April 2019

Multivariate Analysis of Variance ("MANOVA"), the difference between the variables Perceived Desirability and Perceived Feasibility becomes visible. From the test results, according to Pillai's Trace, Wilks' Lambda, Hotelling's Tracem and Roy's Largest Root, all indicators have very significant differences between the two groups. In the Wilks' Lambda test results, the result is 0.554, at F (6.52) with a value of 6.983 , with a P-value $=0.000$, which is said to be less than $<5 \%$ while Partial $\mathrm{n} 2$ is 0.446 .

Table 2 Descriptive Statistics, Summary of 'Don't Want to be Technopreneur' and 'Want to be Technopreneur'

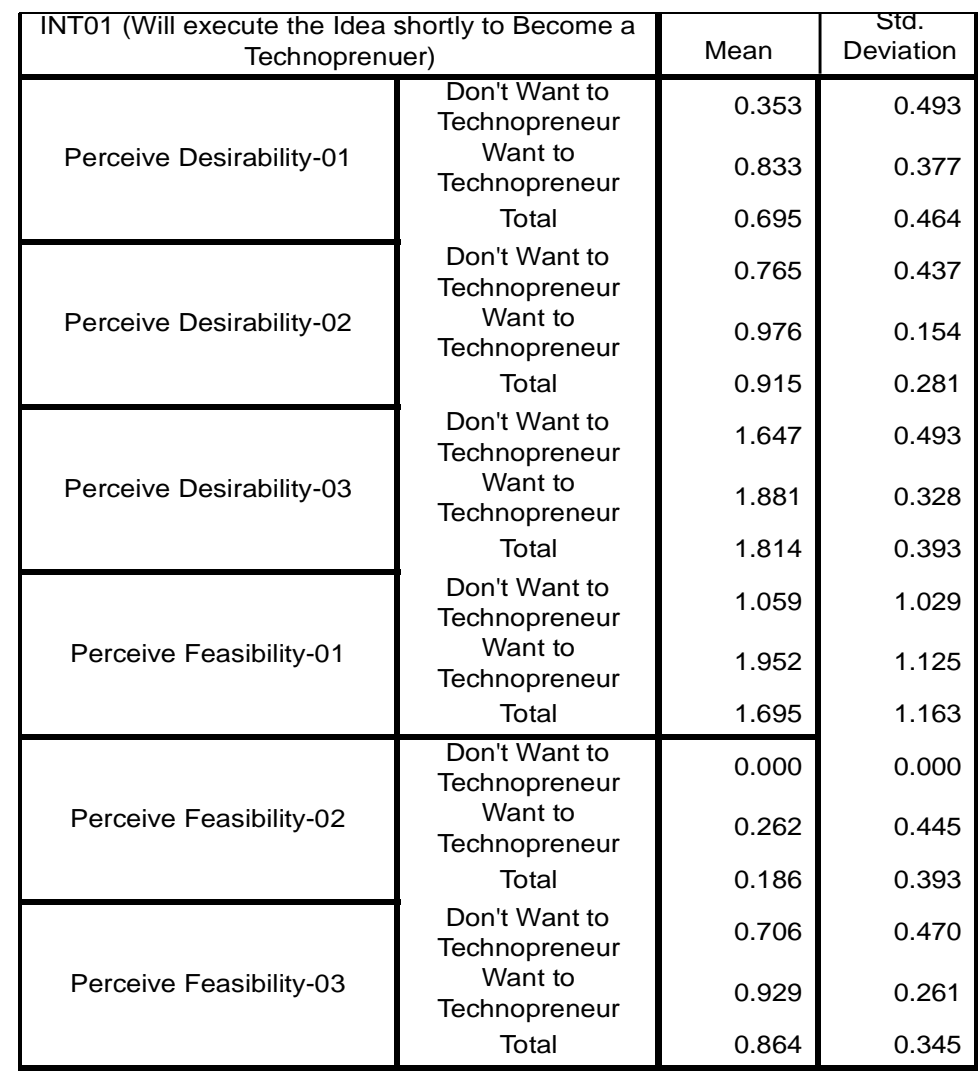

Note: Perceive Desirability- 01 = Generating Idea, Perceive Desirability$02=$ Interesting to Put Ads in Social Media, Perceive Desirability-03 = Interest to become Techno-Interest, Perceive Feasibility-01 = Executing the Idea, Perceive Feasibility-02 = Implementing the Idea, and Perceive Feasibility-0 3 = Interesting to Make MVP (Minimum Viable Product). 
Eka Sudarmaji, Mira Munirah / Alternative Model for Putting Indonesian Young Digital Talent in Business

By using statistical analysis, there are significant differences in the variables Perceived Diserability-01, Perceived Diserability-02, Perceived Diserability-03, Perceived Feasibility-01, Perceived Feasibility-02, and Perceived Disability-03 between the Observed group and the control group. To analyze the effects or effects of work \& innovation-based learning on the two groups, the MANOVA analysis is also used where the NEGD model is tested to predict student desires (Entrepreneurial Intentions) in a high educational institution environment. Indicators of mean and standard deviation of variables Perceived Diserability-01, Perceived Diserability-02, Perceived Diserability-03, Perceived Feasibility-01, Perceived Feasibility-02, and Perceived Disability-03 which affect student desires (Entrepreneurial Intentions) are showed to have very significant results between the two groups. Table 2 shows the differences in the mean and standard deviation indicators between the two groups.

Table 3 Analysis of Variance (ANOVA)

\begin{tabular}{|c|r|r|r|r|r|r|}
\hline Variables & $\begin{array}{c}\text { Type III Sum of } \\
\text { Squares }\end{array}$ & $\mathbf{d f}$ & $\begin{array}{c}\text { Mean } \\
\text { Square }\end{array}$ & $\mathbf{F}$ & Sig. & $\begin{array}{c}\text { Partial ETA } \\
\text { Squared }\end{array}$ \\
\hline Perceive Desireibility-01 & 2.793 & 1 & 2.793 & 16.385 & 0.000 & 0.223 \\
\hline Perceive Desireibility-02 & 0.541 & 1 & 0.541 & 7.646 & 0.008 & 0.118 \\
\hline Perceive Desireibility-03 & 0.662 & 1 & 0.662 & 4.554 & 0.037 & 0.074 \\
\hline Perceive Feasibility-01 & 9.663 & 1 & 9.663 & 8.000 & 0.006 & 0.123 \\
\hline Perceive Feasibility-02 & 0.830 & 1 & 0.830 & 5.828 & 0.019 & 0.093 \\
\hline Perceive Feasibility-03 & 0.600 & 1 & 0.600 & 5.417 & 0.024 & 0.087 \\
\hline
\end{tabular}

The Anova testing conducted at the level of 0.025 (two tailed) on Perceived Diserability-01 has an F-value $(1.57)=16.385$, p-value $=0.000$, and partial ETA square n2 $=0.093$, Perceived Diserability-02 has an F-value (1.57) $=7,646$, p-value $=0.008$ and partial ETA square $\mathrm{n} 2=0.118$, Perceived Diserability-03 has an F-value $(1.57)=4,554$, p-value $=0.037$ and partial ETA square $\mathrm{n} 2=0.123$, Perceived Feasibility-01 has an F-value $(1.57)=8,000$, pvalue $=0.006$, and partial ETA square $\mathrm{n} 2=0.074$, Perceived Feasibility-02 has an F-value $(1.57)=5.828, \mathrm{p}$-value $=0.019$, and partial ETA square $\mathrm{n} 2=0.093$, and Perceived Feasibility-03 has an F-value $(1.57)=5,417$, p-value $=0.024$, and partial ETA square $\mathrm{n} 2=0.087$. 
From the results of individual ANOVA analysis, all the values from the observed group or students who are given work \& innovation-based learning training can be said to have a higher Entrepreneurial Intentions than the control group that is not given work $\&$ innovation-based learning training. The results of this study are in line with the results of Nasip and Eka Sudarmaji's research (2017), which stated that training has a significant impact on the ability of entrepreneurs in their groups (experimental groups) to generate bigger and more innovative business ideas. This is similar to the results obtained by Muñoz et al. (2011) conducted on 1,800 students from three different Nottingham University campuses. Karimi et al. (2014), through their model of providing training, concluded that training can provide abilities that can become new skills to be able to act creatively and to identify new business ideas or new opportunities. All ANOVA analysis results can be seen in Table 3 above and Table 4 below.

Table 4 Comparison between Observed and Control Groups

\begin{tabular}{|c|c|c|c|c|c|}
\hline \multirow{2}{*}{\multicolumn{2}{|c|}{ Dependent Variable }} & \multirow[b]{2}{*}{ Mean } & \multirow[b]{2}{*}{ Std. Error } & \multicolumn{2}{|c|}{ 95\% Confidence Interval } \\
\hline & & & & $\begin{array}{l}\text { Lower } \\
\text { Bound }\end{array}$ & $\begin{array}{l}\text { Upper } \\
\text { Bound }\end{array}$ \\
\hline \multirow{2}{*}{ Perceive Desireibility-01 } & Group Kontrol & 0.353 & 0.100 & 0.152 & 0.553 \\
\hline & Group Observe & 0.833 & 0.064 & 0.706 & 0.961 \\
\hline \multirow{2}{*}{ Perceive Desireibility-02 } & Group Kontrol & 0.765 & 0.065 & 0.635 & 0.894 \\
\hline & Group Observe & 0.976 & 0.041 & 0.894 & 1.058 \\
\hline \multirow{2}{*}{ Perceive Desireibility-03 } & Group Kontrol & 1.647 & 0.092 & 1.462 & 1.832 \\
\hline & Group Observe & 1.881 & 0.059 & 1.763 & 1.999 \\
\hline \multirow{2}{*}{ Perceive Feasibility-01 } & Group Kontrol & 1.059 & 0.267 & 0.525 & 1.593 \\
\hline & Group Observe & 1.952 & 0.170 & 1.613 & 2.292 \\
\hline \multirow{2}{*}{ Perceive Feasibility-02 } & Group Kontrol & 0.000 & 0.092 & 0.183 & 0.183 \\
\hline & Group Observe & 0.262 & 0.058 & 0.145 & 0.379 \\
\hline \multirow{2}{*}{ Perceive Feasibility-03 } & Group Kontrol & 0.706 & 0.081 & 0.544 & 0.868 \\
\hline & Group Observe & 0.929 & 0.051 & 0.826 & 1.031 \\
\hline
\end{tabular}

\section{CONCLUSION AND IMPLICATION}

Learning through work \& innovation-based learning or lessons on how to actually target customers in the business world provides new insights for students, for e-commerce courses in particular, and entrepreneurship courses in general. In addition, several things can also be taught to prospective 
millennipreneurs to carry out their functions as entrepreneurs in the future, for example business negotiations, business planning, targeting customers / customer pitching, market research, business plans, and so forth.

Work \& innovation-based learning in targeting customers is a lesson on how advertisements can deliver desired results. Successful pitching must show that marketers can use marketing budgets effectively to create greater value for the brand or products and services offered. Pitching by sending advertisements to relevant customers can empower marketers to reach and target audiences on a larger scale, through segment division or demographic targeting such as gender, age, education, and so on. This study found that work \& innovation-based learning inspires and has a moderate level and impact on entrepreneurial intentions in the field of technopreneurship.

The strong value of desire (desirability) and confidence (feasibility) of prospective millennipreneurs can be understood, because students today view that entrepreneurship is their career goal after college. This is in line with the university program, which is to convey knowledge on entrepreneurship in the syllabus through entrepreneurship education. Collaborative programs with several similar or parallel courses at the university level will help increase awareness and entrepreneurship mindset of students. Future researches are expected to be comparative and sustainable assessments to test the effectiveness of learning models through work $\&$ innovation-based learning. Work $\&$ innovation-based learning simultaneously may include several variables drawn from several entrepreneurship programs needed to identify characteristics, such as academic approaches, goals, contents, and so on.

\subsection{Research Limitations}

One of the most important learning methods of work \& innovation-based learning that uses Lean Startup Methodology (LSMs) is that prospective entrepreneurs start business with hypotheses, by predicting what should happen when products are introduced. They are experimenting to find ways to build a sustainable business even when experiments produce negative results; in the form of failure. Failure is proven to affect the next strategy in running a business. 
One of the most important lessons from the scientific method - 'if you don't fail, you can't learn'.

The author realizes that this research did not arrive at the actual experimental process and resulted in failure. While in the Lean Startup Model, experiments are more than theoretical; but also, in producing the first product in running a business. Therefore, we believe there are many possibilities of more interesting events that we cannot find in this very short study, especially on the relationship between "Experiments" and "Failures".

\subsection{Suggestion}

This research is believed to help universities and the government in efforts to build new entrepreneurial candidates. More time is needed including factors or variables that must be added to similar researches in the future. Therefore, those researches can provide more detailed results, especially in explaining how the implications for course practices that use work $\&$ innovation-based learning with Lean Startup Methodology (LSMs) provide better results in influencing prospective young entrepreneurs.

\section{REFERENCES}

Ajzen, I. \& Fishbein, M. 2000. Attitudes and the Attitude-Behavior Relation: Reasoned and Automatic Processes. European Review of Social Psychology, 11(1), 1-33.

Baron, R.A. 2004. Opportunity recognition: A Cognitive Perspective. In Academy of Management (pp. A1-A6).

Barrett, M., Davidson, E., Prabhu, J., \& Vargo, S. L. (2015). Service Innovation in the Digital Age: Key Contributions and Future Directions. MIS Quarterly, 39(1), 135-154.

Barron, A.E., Kemker, K., Harmes, C., \& Kalaydjian, K. 2003. Large-Scale Research Study on Technology in K-12 Schools: Technology Integration as It Relates to the National Technology Standards. Journal of Research on Technology in Education, 35(4), 489-507.

Chen, J. 2006. Development of Chinese Small And Medium-Sized Enterprises, 13(2), 140-147. 
Eka Sudarmaji, Mira Munirah / Alternative Model for Putting Indonesian Young Digital Talent in Business

Conner, M. \& Armitage, C.J. 1998. Extending the Theory of Planned Behavior/ : A Review and Avenues for Further Research. Journal of Applied Social Psychology, 28(15), 1429-1464.

Crant, M. 1996. The Proactive Personality Scale as a Predictor of Entrepreneurial Intentions. Journal of Small Business Management, 34(3), 42-49.

Davidsson, P. 2011. Nascent entrepreneurship. Retrieved from http:// www.elgaronline.com/view/Research_Reviews/9781849801379/9

DeTienne, D.R. \& Chandler, G.N. 2004. Opportunity Identification and Its Role in the Entrepreneurial Classroom: A Pedagogical Approach and Empirical Test. Academy of Management Learning \& Education, 3(3), 242-257.

Enkel, E., Bell, J., \& Hogenkamp, H. 2011. Open Innovation Maturity Framework. International Journal of Innovation Management Vol. 15, (6), 1161.

Fiet, J.O. 2007. A prescriptive analysis of search and discovery. Journal of Management Studies, 44(4), 592-611.

Gaglio, C.M. \& Katz, J.A. 2001. The Psychological Basis of Opportunity Identification: Entrepreneurial Alertness. Small Business Economics. CEUR Workshop Proceedings, 1225 (February), 41-42.

Galloway, L. \& Brown, W. 2002. Entrepreneurship Education at University: A Driver in the Creation of High Growth Firms? 44(8/9), 398-405.

Goodwin, N., \& Martam, I. 2014. Indonesian Youth in the 21st Century. Indonesia, UNFPA, Http://Indonesia.Unfpa.Org/Application/Assets/Publications/Indonesian_Youth_in_the_21st_Century_(Youth_Mapping).Pdf.

Guiso, L. 2016. Is Entrepreneurship Contagious? World Economic Forum, Https://Www.Weforum.Org/Agenda/2016/04/Is-Entrepreneurship-Contagious.

Hagen, S. 2008. From Tech Transfer to Knowledge Exchange: European Universities in the Marketplace. In The University in the Market (pp. 103-117). London: Portland Press.

Henderson, R. \& Robertson, M. 2000. Who Wants to be an Entrepreneur? Young Adult Attitudes to Entrepreneurship as a Career. Career Development International, 6(6), 279-287.

Japan-ASEAN Integration Fund (JAIF). 2017. Methodology of Training Programs (COBLAS).

Karimi, S., Biemans, H.J.A., Lans, T., Aazami, M., \& Mulder, M. 2014. Fostering Students' Competence in Identifying Business Opportunities in 
Entrepreneurship Education. Innovations in Education and Teaching International, 3297 (October 2015), 1-15.

Krueger Jr., N.F. \& Brazeal, D.V. 1994. Entrepreneurial Potential and Potential Entrepreneurs. Entrepreneurship Theory and Practice, 18, 91-104.

Krueger Jr., N.F., Reilly, M.D., \& Carsrud, A.L. 2000. Competing Models of Entrepreneurial Intentions. Journal of Business Venturing, 15(5), 411-432. Krueger, N.F. 2003. The Cognitive Psychology of Entrepreneurship. In Handbook of Entrepreneurship Research, an Interdiciplinary Survey and Introduction, Zoltan J. Acs (ed), School of Public Policy, Georgia Mason University (pp. 105-140). Springer, Virginia.

Kumara, P.A.P.S. 2012. Undergraduates' Intention towards Entrepreneurship: Empirical Evidence from Sri Lanka. Journal of Enterprising Culture, 20(1), $105-118$.

Lal, K. 2004. E-Business and Export Behavior/ : Evidence from Indian Firms. In World Development (Vol. 32, pp. 505-517). Elsevier.

Lazear, E.P. 2005. Entrepreneurship. Journal of Labor Economics, 23(4), 649680.

Maksum, A. 2015. Kurikulum dan Pembelajaran di Perguruan Tinggi: Menuju Pendidikan yang Memberdayakan. Seminar Nasional Hasil Penelitian Pendidikan dan Pembelajaran, 25-26 April 2015.

Mansor, M. \& Othman, N. 2011. CoBLAS: Inculcating Entrepreneurial Culture among Higher Education Institutions' Students. International Journal of Social Science and Humanity, 1(1), 86-91.

Moghavvemi, S., Salleh, N.A.M., \& Abessi, M. 2013. Determinants of ITRelated Innovation Acceptance and Use Behavior: Theoretical Integration of Unified Theory of Acceptance and Use of Technology and Entrepreneurial Potential Model. Social Technologies, 3(2), 243-260.

Muñoz, C.A., Mosey, S., \& Binks, M. 2011. Developing Opportunity-Identification Capabilities in the Classroom: Visual Evidence for Changing Mental Frames. Academy of Management Learning and Education, 10(2), 277295.

Nasip, I., \& Sudarmaji, E. 2017. Model Bisnis Kanvas: Alat untuk Mengidentifikasi Peluang Bisnis Baru bagi Pengusaha UKM Indonesia. In 1st National Conference on Business and Entrepreneurship. Surabaya: Universitas Ciputra. 
Eka Sudarmaji, Mira Munirah / Alternative Model for Putting Indonesian Young Digital Talent in Business

Organisation for Economic Co-Operation and Development (OECD). 2001. Putting the Young in Business. In Policy Challenges for Youth Entrepreneurship, LEED Notebook No.29 (pp. 87-89).

Osterwalder, A. \& Pigneur, Y. 2010. Business Model Generation: A Hits Book for Visionaries, Game Changers, I-Challengers (pp. 26-47).

Peterman, N.E. \& Kennedy, J. 2003. Enterprise Education: Influencing Students' Perceptions of Entrepreneurship. Entrepreneurship Theory and Practice, 28(2), 129-144.

Shadish, W.R., Cook, T.D., \& Campbell, D.T. 2002. Experimental and QuasiExperimental Designs for Generalized Causal Inference. Belmont, CA: Wadsworth, Cengage Learning.

Singh, I., Raut, D.R.D., \& Prasad, D.T. 2012. Entrepreneurial Intent - A Review of Literature. In AIMS International Conference on Management, Vol. 9 (pp. 201-207).

Singh, R.K., Garg, S.K., \& Deshmukh, S.G. 2010. The Competitiveness of SMEs in a Globalized Economy: Observations from China and India. Management Research Review, 33(1), 54-65.

Steel, P. \& Konig, C.J. 2006. Integrating Theories of Motivation. Academy of Management Review, 31(4), 889-913.

Straub, E.T. 2009. Understanding Technology Adoption: Theory and Future Directions for Informal Learning. Review of Educational Research, 79(2), 625-649.

Sudarmaji, E. \& Ambarwati, S. 2018. Fostering Nascent Entrepreneur: Unified Theory of Acceptance and Use of Technology and Entrepreneur Potential Model within Higher Student's Intention. Sci. Int. (Lahore), 30(2), 271-278.

Thrikawala, S.S. 2011. The Determinants of Entrepreneurial Intention among Academics in Sri Lanka. In International Conference on Economics and Finance Research (Vol. 4, pp. 454-458).

Veciana, J.M., Aponte, M., \& Urbano, D. 2005. University Students' Attitudes towards Entrepreneurship/: A Two Countries Comparison. International Entrepreneurship and Management Journal, 1, 165-182.

Venkataraman, S. \& Sarasvathy, S.D. 2000. Strategy and Entrepreneurship: Outline of an Untold Story. In Handbook of Strategic Management (pp. 650-658). Oxford, UK: Blackwell Publishers. 
Review of Management and Entrepreneurship

Volume 03, Number 01, April 2019

Wang, W., Lu, W., \& Millington, J.K. 2011. Determinants of Entrepreneurial Intention among College Students in China and USA. Journal of Global Entrepreneurship Research, 1(1), 35-44.

Wright, M., \& Fu, K. 2015. University Spin-outs/: What do we know and what are the policy implications? Evidence from the UK. Journal of Innovation Management, 3(4), 5-15. 